\title{
Aile İçi Şiddet ve Çocuklar Üzerindeki Etkileri: Temel Kavramlar, Güvenlik Planı Hazırlama ve Alternatif Tedavi Model Örnekleri
}

\author{
Domestic Violence and Its Effects on Children: \\ Fundamental Concepts, Safety Planning and \\ Examples of Alternative Treatment Models
}

Melis Sedef Kahraman, Gökçe Çokamay

\begin{abstract}
$\ddot{0 z}$
Aile içi şiddet bir aile bireylerinin birbirlerine karşı uyguladığı birtakım saldırgan ve kontrolcü davranışlar olarak tanımlanmaktadır ve bu davranışlar sıkıkla tekrarlayıı davranış kalıpları olarak ortaya çıkmaktadır. Araştırmalar şiddet olaylarının büyük bir kısmının çocukların gözleri önünde yaşandığını ortaya koymaktadır. Aile içi şiddete doğrudan maruz kalma ya da tanık olma çocuklarda benzer duygusal-davranışsal sorunlarla sonuçlanmaktadır. Bu makalede aile içi şiddete maruz kalan farklı yaş gruplarındaki çocukların verdikleri farklı tepkilere değinilmiştir. Güvenlik planı hem çocuklar hem de aile içi şiddet mağdurları için Batı kültürlerinde sıkıkla kullanılan ancak Türkiye'de henüz yaygın bir şekilde kullanılmadığı gözlenen bir yöntemdir. Bu makale kapsamında güvenlik planı hazırlama aşamaları ve şiddete maruz kalan çocukların tedavisinde kullanılabilecek alternatif tedavi modelleri aktarılmıştır.

Anahtar sözcükler: Aile içi şiddet, çocuklar, güvenlik planı, tedavi modelleri.
\end{abstract}

\begin{abstract}
Domestic violence is defined as coercive and controlling behaviors that family members show toward each other. These behaviors are frequently seen as repetitive behavior patterns. Research indicates that many domestic violence incidents happen in the presence of children. Being exposed to domestic violence or witnessing domestic violence has similar emotional-behavioral problems in children. In this article, we emphasized different reactions of children to domestic violence within different age groups. Safety planning is a commonly used method in Western cultures for professionals either working with adult victims or child victims of domestic violence. Unfortunately, the importance of safety planning is not yet utilized in Turkey. In this article, the phases of safety planning and three different alternative treatment methods that have been proven successful for working with children who were exposed to domestic violence are explained.
\end{abstract}

Key words: Domestic violence, children, safety planning, treatment models. 
AİLE İÇí ŞíDDET duygusal istismardan başlayarak ölümle sonuçlanan fiziksel şiddet vakalarına kadar çeşitlilik gösteren bir kavramdır. Aile içi şiddet, kadına/eşe yönelik şiddet kavramları sıklıkla beraber kullanılan kavramlardır ancak şiddet gösteren ya da mağdur olan kişi aile bireylerinden her hangi biri ya da bir kaçı olabilmektedir. Kadına/eşe yönelik şiddet kişinin hali hazırda ya da geçmiş eşlerine karşı sergilenen saldırgan ve zorlayıcı davranışlarını tanımlamaktadır (UNICEF 2006). Aile içi şiddet genel olarak tek bir olaydan ibaret değildir ve şiddeti sergileyen kişinin kurbana karşı kullandığı davranış kalıbı olarak görünmektedir. Aile içi şiddet fiziksel, cinsel, psikolojik ve hatta ekonomik olmak üzere farklı şekillerde gözlenebilmektedir (Ganley 1995). Dünya Sağlık Örgütü 2013 verilerine göre, kadınların \%35’i yaşamları boyunca en az bir kez eşleri ya da eşleri olmayan kişiler tarafindan cinsel ya da fiziksel şiddete maruz kalmaktadır. Türkiye'de Kadına Yönelik Aile İçi Şiddet Araştırması sonuçları da benzer bir şekilde kadınların \%37.5'inin yaşamları boyunca en az bir kez fiziksel ya da cinsel şiddete maruz kaldıklarını göstermektedir (TÜİK 2014).

Şiddetin ne kadarının çocukların gözlerinin önünde gerçekleştiği tam olarak bilinmemekle birlikte, çocuklar bu sürecin görünmez mağdurları olarak kabul edilmektedir (Osofsky 1995). Amerika'nın 900.000 nüfuslu ve suç oranı genel ülke ortalamasının altında olan Pennsylvania eyaletindeki Northeast bölgesinde yürütülen bir çalışmada polis birimlerinin bir yıl boyunca aile içi şiddet konusunda aldığ miştir. Buna göre aile içi şiddet olaylarının neredeyse yarısının çocukların varlığında gerçekleştiği, bu olayların \%81'inde de çocukların doğrudan şiddete maruz kaldığı görülmüştür (Fantuzzo ve Fusco 2007). UNICEF’in Birleşmiş Milletler Sekreterliği tarafından çocuklara yönelik şiddete ilişkin toplanan verilerden yararlanarak hazırladığı rapora göre, dünya çapında şiddete maruz kalan çocuk sayısının 275 milyon civarında olduğu, Türkiye'de ise şiddete maruz kalan çocuk sayısının 2 ila 6.2 milyon aralığında olduğu tahmin edilmiştir (UNICEF 2006). Aynı rapora göre bazı ülkelerden veri toplanamamış olması, aile içi şiddetin genel olarak gizlenmesi ve ilgili kurumlara rapor edilmemesi nedeniyle durumun oldukça kritik olduğu düşünülmektedir.

$\mathrm{Bu}$ çalışmada ise aile içi şiddetin görünmez mağdurları olan çocukların şiddet sürecinden nasıl etkilendiğinin tanımlanması ve bu süreçte önleme ve tedavi çalışmalarının ana hatlarının betimlenmesi amaçlanmıştır. Bu genel amaçla, öncelikle aile içi şiddet kavramı, türleri, yaygınlığı ayrıntılı bir şekilde ele alınmış, ardından Türkiye'de konu ile ilgili yapılan çalı̧̧malara yer verilmiştir. Aile içi şiddet kavramının ayrıntılı bir şekilde ele alınmasının ardından çocuk istismarı ve ihmaliyle ilgili kavramlar tanımlanmıştır. Çalışmanın devamında aile içi şiddete maruz kalmanın çocukların ruh sağlığı üzerindeki etkilerine değinilmiş olup bu yazı kapsamında aile içi şiddetin çocuklar üzerindeki etkileri yaş grupları bağlamında ele alınmıştır. Son kısımda ise aile içi şiddete maruz kalan çocuklar için bir güvenlik planı oluşturma süreci ve alternatif tedavi modelleri sunulmuştur. Bu bilgilerin Türkiye'de yapılacak yeni uygulamalara 1ş1k tutacağ düşünülmektedir.

\section{Aile İçi Şiddet: Temel Kavramlar ve Türkiye'deki Durum}

Dünya Sağlık Örgütü çocukların aile içi şiddete maruz kalmalarını uzun vadede olumsuz sonuçları olan küresel bir sorun olarak değerlendirmektedir (WHO 2014). Ancak aile içi şiddetin çocuklar üzerindeki etkisini kavrayabilmek için öncelikli olarak aile içi şiddete ilişkin temel kavramların ve aile içi şiddet verilerinin bilinmesi büyük önem 
taşımaktadır. Aile içi şiddet cinsel şiddet, fiziksel şiddet, duygusal şiddet ve ekonomik kontrol olmak üzere dört farklı ana başlık altında incelenebilir.

1. Cinsel Şiddet: Cinsel şiddet kavramına eşe yönelik istismar bağlamında bakıldığında kişiyi istemediği cinsel davranışları yapmaya zorlama, kişi istemediği halde cinsel ilişkiye zorlama, cinsel yönelimine bağlı davranışları değersizleştirme, taciz etme, cinsel ilişki sırasında güç kullanmanın cinsel şiddet olarak tanımlandığı görülmektedir (Mor Çatı Kadın Sığınağı Vakfı 2016). Eşe yönelik cinsel istismar niteliğinde değerlendirilebilecek birçok davranış olup hepsinin temelinde istismar eden kişinin aynı mesajı yatmaktadır: kurbanın bedeni üzerinde kurban değil istismarcı eş/partner söz sahibidir (Ganley 1995). Cinsel ilişkiye zorlanmanın tanıdık kişiler ya da eşler tarafından daha fazla olduğu bilinmektedir. Çok sayıda kadının hayatının bir döneminde cinsel zorlanmaya maruz kaldığı tahmin edilmektedir. Özellikle çocukluk yıllarında aile bireyleri tarafindan cinsel şiddete maruz kalan kız çocukları ilerleyen yaşlarda yine akrabaları tarafından mağdur edilebilmektedirler (Şenol ve Yildiz 2013).

2. Fiziksel Şiddet: Eşe yönelik fiziksel şiddet sıklıkla istismar eden eşin ya da partnerin kurbanı yumruklaması, tokat atması, vurması, 1sırması, çimdiklemesi, tekmelemesi, saçını çekmesi, itip kakması, yakması, boğazını sıkması, bir aletle vurması, bir alet batırması şeklinde gözlenmektedir (Mor Çatı Kadın Sığınağı Vakfı 2016). Kadının uygulanan fiziksel şiddete itiraz edememesi, evi terk edememesi, yardım çağrısına karşılık sabırlı olmasının söylenmesi, fiziksel şiddetin devam etmesine neden olmaktadır. Öte yandan kadının haklarını bilmemesi ve bilse de kendini savunamaması bu şiddetin devam etmesine neden olmaktadır (Şenol ve Yıldız 2013).

3. Duygusal Şiddet: Eşe yönelik duygusal şiddet kavramına bakıldığında bu kavramın sözel saldırılar ve aşağılamaları içeren duygusal saldırıların yanı sıra şiddet ve zarar verme tehdidi, ev eşyalarına ve evcil hayvanlara zarar verme, çocukları kullanma ve yalıtımı içerdiğini söylenebilir (Ünal 2008). Başbakanlık Kadının Statüsü Genel Müdürlüğü’nün (2009) kadına yönelik aile içi şiddet araştırmasına göre, Türkiye genelinde evli kadınların yüzde 44'ü duygusal şiddete maruz kaldıklarını, her dört kadından biri de son bir yıl içinde duygusal şiddeti deneyimlediğini belirtmiştir.

4. Ekonomik Şiddet/Kontrol: Ekonomik şiddet ya da kontrol ise istismarcı eşin kurbanın ailenin ekonomik bütün kaynaklarına ulaşımını kontrol altında tutması olup söz konusu kaynaklar; para, sigorta, yemek, kalacak yer, ulaşım araçları olabilir (Ganley 1995). Bu ekonomik kaynakları bir kontrol aracı olarak kullanan istismarcı eşin davranışları yalnızca kurbanın değil çocukların da zarar görmesi ile sonuçlanabilir. Ekonomik olarak kontrol sağlama kadını ekonomik olarak bağımlı yapan ve yoksulluğa sürükleyen bir şiddet şeklidir. Ekonomik kontrol sağlamaya yönelik olan bu tutum aynı zamanda ülkenin de kalkınmasını engelleyen bir sorun olmaktadır (Duyan 2011).

Aile içi şiddetin somut olarak görülmesi için bu konuyla ilgili yapılan araştırmaların ortaya koyduğu sonuçlar önemlidir. Başbakanlık Kadının Statüsü Genel Müdürlüğü (2009) tarafindan yapılan ve örneklemini Türkiye'de yaşayan 15-59 yaş aralığındaki kadınların oluşturduğu, kadına yönelik aile içi şiddet araştırması sonuçlarına göre, 
Türkiye'de evli kadınların yüzde 39'u fiziksel şiddete, yüzde 15'i cinsel şiddete ve yüzde 42'si bu iki şiddet türünden birine maruz kalmaktadır. Ayrıca cinsel şiddet ile fiziksel şiddetin iç içe yaşandığı durumların oldukça fazla olduğu, kadına yönelik şiddetin yaşanılan bölge, eğitim ve refah düzeyi bakımından farklılaşmadığı, yaşam standartlarındaki artışla birlikte şiddete maruz kalma durumunun azaldığı ancak refah düzeyindeki artışın kadının şiddetten korunduğuna ilişkin bir bulgu olmadığı belirtilmiştir. Diğer bir çarpıcı bulgular ise, boşanmış/ayrı yaşayan kadınların yüzde 73'ü fiziksel şiddet yaşadıklarını, bekar kadınların ise yüzde 9'u erkek arkadaş/nişanlı/sözlü tarafindan fiziksel şiddete uğradığını ifade etmiştir.

Kadına yönelik şiddet ve aile içi şiddet konusunda yapılmış araştırmalara göre şiddet yaşayan kadınların ruh sağlıkları yaşanan bu duruma bağlı olarak bozulmaktadır. Şiddetin farklı türlerine maruz kalan kadınların depresyon (Kıvrak ve ark. 2015), travma sonrası stres bozukluğu gibi bozukluklar geliştirdiği ve intihar girişiminde bulundukları (Temiz ve ark. 2014) görülmüştür. Sığınma evinde kalan ve eşiyle birlikte yaşayan şiddet mağduru kadınların ruhsal belirtileri incelendiğinde bu kadınların somatizasyon, obsesif kompulsif bozukluk, kişilerarası duyarlılık, kaygı, uyku ve yeme bozuklukları, suçluluk duyguları gibi ruhsal sorunlar geliştirdikleri bulunmuştur (Gezen ve Oral 2013). Ne yazık ki bu durumdan etkilenen tek kişi olayın mağduru olmamaktadır. Annenin ruh sağllğ̣ çocuğun gelişiminde önemli bir faktör olarak görünmektedir (Lewis ve ark. 2015).

\section{Çocuğun Aile İçi Şiddete Maruz Kalması ve Çocuk İstismarı}

Aile içi şiddet ile çocuk istismarı sıklıkla bir arada görülmektedir (Waugh 2002, UNICEF 2006, MacMillan ve ark. 2013). Bu durumda çocuk fiziksel şiddete ya da diğer istismar edici davranışlara tanıklık edebilir, bunun yanı sıra istismar eden eş ya da partner çocuğa doğrudan vurabilir ya da çocuğu fiziksel olarak incitebilecek davranışlarda bulunabilir (Davies ve ark. 1998, Barran 2014). Ayrıca eşleri tarafindan istismara uğrayan kadınların çocuklarını istismar etmeleri de söz konusudur ve alan yazında çok fazla karşılaşılmamakla birlikte aile içi şiddetin bir sonucu olarak ele alınmaktadır (Peled 2011). Şiddete doğrudan maruz kalan çocuklar kadar dolaylı olarak maruz kalan çocuklar da bu durumdan olumsuz etkilenirler ve profesyonel yardım almaları gereklidir.

Sözü edilen durumlar genel olarak çocuğa kötü muamele (child maltreatment) başlığ1 altında çocuk istismarı (child abuse) ya da çocuk ihmali (child neglect) şeklinde sınıflandırılmaktadır. Bu kavramların şu şekilde tanımlayabiliriz;

Çocuğa kötü muamele 18 yaşın altındaki çocuğun ihmal edilmesi ya da istismar edilmesini kapsayan genel bir terim olup her şekilde fiziksel ve/veya duygusal kötü muamelenin yanı sıra, cinsel istismar, ihmal, tedbirsizlik, ticari ya da diğer türlü sömürülere ilişkin eylemleri içermektedir. Bu eylemler sonucunda çocuk güç, güven ya da sorumluluk ilişkisi bağlamında hayati, gelişimsel ya da sağlıkla ilgili zarar görüyordur ya da zarar görme riski altındadır (WHO 2014).

Çocuk istismarı "0-18 yaş grubundaki çocuğun kendisine bakmakla yükümlü kişi veya kişiler tarafindan zarar verici olan, kaza-dışı ve önlenebilir bir davranışa maruz kalması çocuk istismarıdır ve bu davranışın çocuğun fiziksel, psikososyal gelişimini engelleyen, gerçekleştiği toplumun kültür değerleri dışında kalan ve uzmanı tarafindan da istismar olarak kabul edilen bir davranış olması gerekmektedir” şeklinde tanımlanmıştır 
(Polat 2007). İstismar kavramının anahtar özellikleri, tekrar etmesi, kasıtlı olması, çocuğun fiziksel, zihinsel, psikososyal gelişimini ve sağlığını olumsuz etkilemesidir.

Çocuk ihmali ise çocuğa bakmakla yükümlü kişilerin çocuğun bakım, korunma, beslenme, giyim, eğitim, sağlık gibi gereksinimlerini yeterince yerine getirmemesi, çocuğu tek başına bırakması olarak tanımlanmıştır (Pelendecioğlu ve Bulut 2009).

Tıraşçı ve Gören'e göre (2007) çocuk istismarı ve ihmali durumunda bir yetişkin tarafından çocuğa karşı uygunsuz ya da hasar verici olarak tanımlanan, çocuğun gelişimini engelleyen ya da kısttlayan eylem ve eylemsizlikler söz konusudur. Bu eylem ya da eylemsizliklerin sonucu olarak çocuk fiziksel, ruhsal, cinsel ya da sosyal açıdan zarar görür, sağlık ve güvenliği tehlikeye girer. Bu bağlamda Pelendecioğlu ve Bulut (2009), ihmal ve istismar arasındaki fark için ihmalin pasif davranışlardan, istismarın ise aktif davranışlardan oluşuyor olmasına dikkat çekmiştir.

Alan yazına bakıldığında çocukların ihmal ve istismar edildikleri alanlara dayanarak cinsel, fiziksel ve duygusal istismar/ihmal kavramlarının farklı başlıklar altında tanımlandığ1 görülmektedir. Buna göre çocuğa yönelik cinsel istismar, yetişkinlerin cinsel çıkarları doğrultusunda çocuğu kullanmaları olarak tanımlanmaktadır (Ünal 2008). Tecavüz, ensest, çocuk pornografisi, teşhircilik, cinselliği kışkırtan konuşmalar, pornografik film seyrettirme, cinsel organları okşamaya kadar değişen eylemler cinsel istismar yelpazesi içindedir (Tıraşçı ve Gören 2007). Çocukların cinsel gelişimine gerekli önemin verilmemesi, cinsel istismara karşı korunamaması ya da bu konuda ilgisiz kalınması da cinsel ihmal olarak değerlendirilmektedir (Ünal 2008).

Çocuğa yönelik fiziksel istismar çocuğun kaza dışı yaralanması ya da fiziksel olarak cezalandırılması olarak tanımlanmaktadır. Fiziksel ihmal ise, çocuğun başkaları tarafından, fiziksel gelişim için gerekli olan beslenme, tıbbi bakım, giyim ve korunma gibi temel ihtiyaçlardan yoksun bırakılması ve bunların sağlanmaması durumu olarak ifade edilmektedir (Ünal 2008). İngiltere'de aile içi şiddet konusunda uzmanlaşmış dört farklı merkezin işbirliğiyle yürütülen bir çalı̧̧mada 877 çocuktan oluşan örneklem grubunun \%28'inin aile içi şiddete tanık olmanın yanı sıra doğrudan fiziksel şiddete maruz kaldıkları bulunmuştur (Barran 2014, CAADA 2014). Fiziksel istismar diğer istismar türlerine göre en sık rastlanan ve belirlenmesi en kolay olan istismar türüdür (Tıraşçı ve Gören 2007, Ünal 2008).

Çocuğun duygusal, sosyal ve kişilik gelişimini engelleyici tüm davranışların, duygusal istismar ve ihmal kavramı altında tanımlandığı görülmektedir (Ünal 2008). Çocuğa bağırma, reddetme, aşağılama, küfretme, yalnız bırakma, yanıltma, korkutma, yıldırma, tehdit etme, duygusal bakımdan ihtiyaçlarını karşılamama, yaşın üzerinde sorumluluklar bekleme, kardeşler arasında ayırım yapma, değer vermeme, önemsememe, küçük düşürme, alaylı konuşma, lakap takma, aşırı baskı ve otorite kurma, bağımlı kılma ve aşırı koruma gibi davranışlar duygusal istismar olarak tanımlanabilir (Tıraşçı ve Gören 2007).

Son yıllarda aile içi şiddete maruz kalma da çocuğa kötü muamele kavramının içinde değerlendirilmeye başlanmışır (WHO 2014). Çocuğun aile içi şiddete maruz kalması başlarda çocukların yetişkinler arasında yaşanan şiddet içerikli olaylara doğrudan tanıklık etmesi olarak değerlendirilmiştir (MacMillan ve ark. 2013). Holden’a göre (2003) araştırmalarda sıklıkla kullanılan aile içi şiddete maruz kalma kavramının, araştırmalarda ele alınış biçimi fazlaca değişkenlik göstermektedir. Şiddet içeren olayların çocuklar tarafından doğrudan görülmesi ya da duyulması ile çocukların şiddete doğru- 
dan maruz kalmadan sadece farkında olmaları benzer sonuçlar doğurmaktadır (MacMillan ve ark. 2013). Holden (2003) incelediği araştırmalardan yola çıkarak çocukların şiddete maruz kalma durumlarını on başlık altında sınıflandırmıştır. Buna göre şiddete maruz kalma durumlarının altısı doğrudan, diğer dördü ise dolaylı bir şekilde çocuğun şiddete tanık olması şeklinde değerlendirilmiştir. Bu sınıflamaya göre çocukların aile içi şiddete maruz kalmaları şu başlıklar altında sınıflandırılabilir:

1. Doğum öncesi (Annenin aile içi şiddete maruz kalışı fetüsü etkiler),

2. Müdahale etme (Çocuk sözel ya da fiziksel olarak şiddeti durdurmaya çalışır, annesini savunmaya çalışır ya da anababasına durmalarını söyler),

3. Kurbanı olma (Çocuk olay sırasında kasti ya da kazara sözel ya da fiziksel olarak saldırıya uğrar),

4. Tanıklık etme (Çocuk olaya doğrudan tanıklık eder, saldırıyı izler ya da sözlü saldırıyı doğrudan duyar),

5. Kulak kabartma (Çocuk olayı doğrudan görmez ancak sesler-bağırış, tehdit ve eşyaların kırılma seslerini- duyar),

6. Katılma (Çocuk olaya kendiliğinden dahil olur ya da dahil olmaya zorlanır, casus olarak kullanılır, çocuk da annesi ile alay ederek olaya dahil olur),

7. İlk etkilerini gözleme (Çocuk saldırının hemen ardından ortaya çıkan sonuçları-yaralanma, ambulans, zarar gören eşyalar, yoğun duygular-görür),

8. Olay ardından (Saldırının sonucunda çocuğun hayatında ortaya çıkan değişiklikler-annenin depresyonu, anababalık tarzında değişim, anne ya da babadan ayrılma, yer değiştirme- ile karşı karşıya kalır),

9. Sonradan duyma (Yaşanan saldırı çocuğa doğrudan anlatılır-anababa, kardeşler ya da akrabalar tarafından- ya da çocuk bu konu ile ilgili anlatımlara kulak kabartır),

10. Görünüşte habersiz olma (Saldırı çocuk evde değilken, okuldayken ya da uyuyorken olmuştur ve çocuk saldırıdan habersizdir).

\section{Şiddetin Çocuklar Üzerindeki ve Yaşam Boyu Süren Etkileri}

Aile içi şiddetin çocuklar üzerinde birçok olumsuz etkisi söz konusudur ve bu etkiler şiddetli ve uzun süreli olabilir (UNICEF 2006). İngiltere'de aile içi şiddet konusunda hizmet veren dört merkezin yardımı ile yürütülen bir çalışmaya göre, aile içi şiddete tanık olan çocukların \%52'si davranış sorunları geliştirmiş, \%39'u okula uyum problemleri göstermiş, \%25'i istismar edici davranışlar sergilemeye başlamış, \%60'1 ise evde yaşanan şiddet olaylarından kendisinin sorumlu olduğunu belirtmiştir (Barran 2014). Dünya Sağlık Örgütü’ne göre anababasından kötü muamele gören çocuklarda bazı psikolojik, fiziksel ve davranışsal sorunların gelişmesi olasıdır. Bu sorunlar, istismar eden ya da istismar edilen olma, depresyon, sigara içme, obezite, yüksek riskli cinsel davranışlar, istenmeyen hamilelik, alkol ya da madde kullanımı olarak ortaya çıkmaktadir (WHO 2014).

Funzotto ve Fusco (2007) 6 yaş altı çocukların aile içi şiddete tanık olma risklerinin daha yüksek olduğunu bildirmiştir. Aile içi şiddete tanıklık eden küçük çocukların duygusal stres, uyku bozuklukları, yalnız kalma korkusu, gelişim düzeylerinin altında olgunluk, somatik yakınmalar, tuvalet eğitiminde ve dil gelişiminde gerileme gözlenmiştir (Osofsky 1995, 1999, 2005). Başka bir araştırmada ise çocukların bağlanma sorunu, ayrılma kaygısı yaşadıkları ve bu çocukların duygularını dile getirebilecek sözel 
kapasitelerinin henüz yeterli olmasının da bu yaşlarda görülen öfke nöbeti, saldırganlık, ağlama ve sakinleşememe, kayg1 ve umutsuzluğu açıkladığı görülmüştür (Holt ve ark. 2008). Aynı zamanda yeni doğanlar ve küçük çocukların strese karşı savunmasız olduğu ve bu yaşlarda maruz kalınan stresin beyin gelişimini etkilediği (Herman-Smith 2013), yaşamın ilk iki yılında maruz kalınan kişiler arası travmanın özellikle zarar verici olduğu ve çocuğun bilişsel gelişimini doğrudan etkilediği (Enlow ve ark. 2012) bilinmektedir.

Aile içi şiddete tanık olan okul çağı çocuklarının sıklıkla bu konuyla ilgili rahatsız edici düşüncelerinin olduğu ve bu nedenle odaklanma problemleri yaşayabildikleri, kaygı ve uyku bozuklukları, saldırgan ve karşı gelme davranışları olabileceği gibi travma sonrası stres bozukluğuna çok benzer bir tablo da gösterebilecekleri (Osofsky 2005) belirtilmiştir. Genel işlevsellikleri, davranı̧̧ları, sosyal becerileri ve okul performansları yaşadıkları durumdan etkilenebilmektedir (Osofsky 1995). Osofsky’e göre (2005) okul çağı çocuklarının artık kendilerine ve başkalarına ilişkin duygusal farkındalıkları yüksektir, bu nedenle şiddetin nedenleri üzerine kafa yorabilirler, şiddeti durdurmak için neler yapabileceklerini düşünüyor ve bu konuda endişeleniyor olabilirler ve kendilerini suçlayabilirler.

Aile içi şiddete maruz kalan ergenler davranış problemlerinin (agresif, baş kaldırıcı davranışlar, intikam yolları arama) yanı sıra kaygı ve umutsuzluk sergilemektedir. Ayrıca bağlanma sorunları ve kendileri için olumsuz birtakım grupların içine dahil olma gibi durumlarla karşılaşılmaktadır (Osofsky 1995, 2005). Bu dönemde aile içi şiddete maruz kalmanın etkileri aile dışına da yansıyabilmektedir ve ergen sağlıklı akran ilişkileri kuramamaktadır (Holt ve ark. 2008). Ayan (2007) altı, yedi ve sekizinci sınıf ilköğretim öğrencileri ile yürüttüğü çalı̧̧ması sonucunda ailesi tarafindan şiddete maruz kalan ergenlerin saldırganlık eğilimlerinin daha yüksek olduğunu bulmuştur. Ayrıca diğer çalı̧̧malara göre, bu ergenlerin düşük beden kitle endeksine sahip olduğu (Lourenço de Silva ve ark. 2014), aile içi şiddetin erkek ergenlerin madde kullanımıyla ilişkili olduğu (Espelage ve ark. 2013) bulunmuştur. Aile içi şiddetin çocuklarda travma sonrası stres bozukluğuna neden olmasının yanı sıra en az bir ebeveynin şiddet uygulaması ise çocukların pek çok alanda (sosyal, duygusal, davranışsal gibi) uyumsuz bir işlev göstermesine neden olduğu, ergenlerde ise aile içi şiddet eş zamanlı problemleri doğurduğu belirtilmiştir (Margolin ve Vickerman 2011).

Çocukların aile içi şiddetten etkilenme düzeylerinin yaşla ilişkisini inceleyen araştırmalar farklı sonuçlar elde etmiştir. Buna göre, çocukların aile içi şiddetten etkilenmesinin yaştan bağımsız olduğu sonucunun (Wolfe ve ark. 2003, Evans ve ark. 2008) yanı sıra aile içi şiddete daha erken dönemlerde ve daha uzun dönemli maruz kalan çocukların birbirini izleyen gelişimsel süreçlerde daha erken problemler yaşadığını gösteren bir bulguya da (Holt ve ark. 2008) rastlanmıştır. Ancak bu duruma maruz kalan çocukların hangi gelişim döneminde hangi duygusal ve davranışsal özellikleri göstereceğinin bilinmesi bu çocukların belirlenmesi bakımından önem taşımaktadır. Ayrıca maruz kalınan durumla baş etme yollarının geliştirilmesi açısından da bu özelliklerin tanımlanması önemlidir.

Aile içi şiddet çocuklar için olduğu kadar yetişkinler için de travmatik bir deneyimdir. Herman'a (2015) göre aile içi şiddetin diğer travma türlerinden bir farkı da çocuğun güvenlik konusunda ve kendisini korunmaya muhtaç hissettiği durumlarda yöneldiği kişilerden birinin tehlikenin ana kaynağı olmasıdır. Sıklıkla çocuğun bu kişi ile olan iletişimi devam etmektedir. Fiziksel şiddet dönemsel ya da düzensiz şekilde gözlenebilir 
ancak istismarın diğer türleri süreklilik gösterir ve dolayısıly aile içi şiddet doğası gereği kroniktir. Dolayısıyla travmatik deneyim ailenin bütün üyeleri için süreklilik gösterir (Ferencik ve Ramirez-Hammond 2010). Çocukluklarından itibaren aile içi şiddete maruz kalan kişilerin yetişkinlik dönemlerinde bu maruz kalmanın uzun dönemli etkileri gözlenebilir. Roediger'e göre (2009) duygusal, bedensel ya da cinsel istismara maruz kalarak büyümüş kişiler başka kişileri tehlikeli ve kendisine zarar verebilir olarak algılarken kendilerini de değersiz ve istismara karşı savunmasız olarak algılarlar. Diğer kişilerin kendilerini inciteceği, aşağılayacağı, aldatacağı, yalan söyleyeceği, çıkarları için kullanacağ1 yönünde bir beklenti geliştirirler (Young ve ark. 2003). Bu durum bir yandan istismar edilecekleri şüphesiyle ya ilişkiden kaçınmaya ya da yüzeysel ilişkiler yaşamaya, diğer yandan istismar edildikleri ilişkileri sürdürmeye neden olabilir. Ayrıca ilişki içinde zarar görmemek için çeşitli stratejiler geliştirebilir ve bunlardan biri de kendisinin istismarcı olmasıdır (Dobson 2009). Stratejileri her ne olursa olsun başka kişilerin güvenilmez ve istismar edici kendilerinin de istismara mahkum olan kişiler oldukları adeta hayatlarındaki temel paradigma haline gelmiştir (Roedriger 2009).

Aile içi şiddet doğrudan maruz kalan kişi için travmatik bir deneyim olmasına karşın bununla sınırlı kalmamaktadır. Şiddete tanıklık eden, doğrudan ya da dolaylı olarak maruz kalan çocuklar şiddetin etkisini hem kısa hem uzun vadede yaşamaktadır. Söz konusu etkilerin çocuğa kısa ve uzun vadede zarar vermemesi için çeşitli önlemler ve tedavi yöntemlerinin geliştirilmesi ve yaygınlaştırılması oldukça önemlidir. Bu nedenlerle çocuğun kendini koruyabilmesi için bir model olan güvenlik planı hazırlama ve çocuğun iyilik halinin sürdürülmesi için alternatif tedavi yöntemlerinden söz edilmiştir.

\section{Şiddete Maruz Kalan Çocuklarda Güvenlik Planı Hazırlama}

Travmanın en önemli etkilerinden bir tanesi travma kurbanı olan kişinin kendisini güçsüz ve her şeyin kontrolünden çıktığını hissetmesidir (Herman 2015). Bu kişilerin kendilerini güvende ve hayatlarını kontrol edebildiklerini hissetmeleri hem birtakım olumsuz durumlarla baş etme hem de iyileşme sürecinde yardımcı olduğu düşünülmektedir. Bunun için de aile içi şiddet söz konusu olduğunda mağdur kişilerin kendilerini güvende ve kontrolü yitirmediklerini hissetmelerini sağlayan bir yöntemin belirlenmesi önemlidir. Bu yöntem hem aile içi şiddet hem de doğrudan çocuğun istismarı söz konusu olduğunda kullanılabilir.

Güvenlik planı kriz durumundaki kadınlara yardımın vazgeçilmez bir parçası olarak görülmekte ve kadın sığınma evleri ile aile içi şiddet yardım hatları tarafindan kullanılmaktadır (Miller ve ark. 2012, Lindhorst ve ark. 2005). Kadınlarla yapilan güvenlik planları sıklıkla çocukların güvenliğine ilişkin öğeleri de kapsamaktadır. Diğer yandan aile içi şiddete maruz kalan kadınlara yönelik sitelerde kadınlara çocukları ile güvenlik planı hazırlamaları tavsiye edilmektedir (The National Domestic Violence Hotline 2015, Morçatı Kadın Sığınağı Vakfı 2016). Söz konusu güvenlik planları travma odaklı bilişsel davranışçı terapi ve çocuk-ebeveyn psikoterapisi gibi tedavi programlarında da yer almaktadır (Mac Millan ve ark. 2013).

Aile içi şiddetin var olduğu durumlarda ebeveynlerin çocuklarla gözden geçirebilecekleri bazı temel güvenlik stratejileri tanımlanmıştır. İlk olarak çocuğa, sorumluluğunun anneyi korumak değil güvende olmak olduğu açıklanmalıdır. Buna göre çocuklara şiddet olayının ortasında kalmadan nasıl kaçabilecekleri öğretilmeli, gerekirse çocuklarla bunun denemesi yapılmalı, ev içinde çocuk için bazı güvenli olabilecek yerler belirlen- 
meli, çocukla ebeveyn arasında uzaklaşmasını ya da yardım çağırmasını ifade edecek bazı şifre kelimeler/kodlar kararlaştırılmalıdır (Campbell 2001, The National Domestic Violence Hotline 2016).

MacMillan ve arkadaşları (2013) çocuklarla güvenlik planı yaparken aşağıdaki ilkeler ve uygulamaya dönük stratejilerin yararlı olabileceğini öne sürmüşlerdir:

a. Okulda yapılan önleme çalışmalarında cinsel istismara çok fazla değinilmemelidir ve evdeki her tür şiddetin kabul edilemez olduğu belirtilmelidir. Bu şekilde aile içi şiddete ilişkin gizlilik tabusu da yıkılmış olacaktır,

b. Güvenlik kavramı genişletilmeli, yalnızca fiziksel güvenliğe odaklanmak yerine duygusal, manevi güvenlik ve kültürel güvenliğe de vurgu yapılmalıdır,

c. Çocukların yaşlarına ve gelişimsel seviyelerine uygun bilgi verilmelidir,

d. Verilmek istenen mesajlar yardım çağırma, evin içinde bir tehlike olduğunda ev dışında güvenli bir yer arama, güvenilir bir yetişkine söyleme gibi genel güvenlik stratejileri içinde çerçevelenmelidir,

e. $\quad$ Şiddet olduğunda başka çocuklara değil yetişkinlere ihtiyaç olduğu özellikle vurgulanmalıdır

f. $\quad$ Çocuğa her şeye rağmen bazı zararların meydana gelebileceği, bazı tehlikeli durumlarda söz konusu güvenlik stratejilerini uygulayamayabileceği açıklanmalı ve kendisini suçlamasının önüne geçilmelidir,

g. Yine çocuğa şiddet içeren durumların anababalar birlikte yaşamasalar da ayrılık sonrası ya da ziyaretler sırasında taraflar birbirlerini gördüklerinde de ortaya çıkabileceği açıklanmalıdır.

Miller ve arkadaşlarının (2012) okul öncesi çocuklarla yürüttükleri on haftalık güvenlik eğitimi programının ilk dört haftasında duygularını ifade etme ve tanımaya dönük aktiviteler uygulanmıştır. Bu kapsamda aile içi şiddete ilişkin duygular da ele alınmıştır. Beşinci seansta güvenlik planına değinilmiş, sonraki seanslarda üzerinden geçilmiştir. Güvenlik planının yanı sıra, altıncı seansta çatışma çözme stratejileri de ele alınmış ve çocuklarla kavga etmenin alternatifi olabilecek yöntemlere odaklanılmıştır. Son seanslarda aile içi şiddetin ötesinde cinsiyet rolleri de ele alınmıştır. Söz konusu programın sonunda gerçekleştirilen değerlendirmeye göre, okul öncesi çocukların güvenlik stratejilerini öğrenebildikleri ortaya koyulmuşsa da çalışmanın sonuçları bu stratejiler üzerinde daha fazla durulması gerekliliğini göstermiştir.

Başka bir çalışma hizmet sağlayıcılar (sosyal hizmet uzmanları gibi) ile yapılmış ve buna göre hizmet sağlayıcıların çocuklara güvenlik planı hazırlamada doğru yolu kullanma konusunda birtakım çekinceleri olduğu görülmüştür. Bu görevliler aynı zamanda çocuk/ergen ve ailelerle şiddet söz konusu olduğunda ne zaman ve nasıl güvenlik planı oluşturacaklarına ilişkin de zorluklar yaşadıklarını belirtmişlerdir (Horton ve ark. 2014). Dolayısıyla bu eğitimi/hizmeti verecek personelin hem çocuk ve ergenlerin gelişimsel özelliklerini bilmesi hem de kriz durumlarının dinamikleri konusunda bilgi sahibi olmas1 gerekli görünmektedir.

Turnell ve Edwards (1999), sosyal çalışmacıların çocukların güvenliğini sağlama ve güvenlik planı hazırlamadaki uygulamalarını geliştirme üzerine yaptıkları çalışmalarda, sosyal çalışmacıların bu konuda dikkat etmeleri gereken noktalara değinmişlerdir. Genel anlamda sosyal çalışmacıların bu hizmeti alanların birer insan olduklarını ve onların gereksinimlerine odaklanmaları gerektiğini belirtmiştir. Ortada bir istismar olmasa dahi en küçük bir riski bile göz önüne alarak tüm detayları incelemeleri gerektiği belirtilmiş- 
tir (Gibson, 2014).

Çocuğun korunması, sosyal hizmetlerin önemli konularından biri olmuştur ve bu konuda birçok yaklaşım denenmiştir. Turnell (2012), çocuk koruma planı (child protection plan) ve güvenlik planını (safety planning) karşılaştırmalı olarak incelemiştir. Buna göre çocuk koruma planında hizmet sağlayıcılar konunun uzmanı olarak çocukla iletişime geçerler ve aileden sınırlı sayıda kişi bu plana katılırken çok sayıda uzmanın katılımı söz konusudur. Buna karşılık güvenlik planında planı oluşturucu temel kişiler olarak aile ve çocuğun işbirliğine önem verilir. Çocuk koruma planında aileye temasa geçmesi için bir servisler listesi verilir, güvenlik planında ise ailenin çocuğun güvenliği için üzerinde çalışması gereken detaylı kurallar öğretilir. Son olarak çocuk koruma planında aileye katılması gereken toplantılar listesi verilir, hepsi çocuk koruma konferansı sonrası kısa bir süre içinde hazırlanır ve aileler genellikle süreçle ilgili eleştireldir. Güvenlik planında ise aileler ve gerekli sosyal ağın işbirliği için görüşmeler aylar sürebilir, aileler kuralların neden gerekli olduğunu öğrenir ve aileler genellikle süreçle ilgili olumludur (Gibson 2014).

Güvenlik planı oluşturma sürecinin öğretici, tüm aileyi ve gerekli sosyal ağı kapsayan, uzun dönemli ve olumlu bir süreç olduğu söylenebilir. Ancak sürecin etkili ve olumlu bir şekilde geçirilmesi bu hizmet sağlayıcıların bu konuda gerekli eğitimi almış ve uzman olmaları gereklidir. Aynı zamanda aileden güvenilir kişilerin listeye alındığı ve olumlu bir yaklaşımla bu kişilerin etkin katılımları desteklenmelidir. Her şeyden önce bu güvenlik planını öğrenme sürecinde çocuğun ruh sağllğg düşünülmeli ve bilgilerin çocuğun gelişimine uygun, kendini güvende hissettiği bir şekilde verilmesi gözetilmelidir.

\section{Şiddete Maruz Kalan Çocuklar İçin Farklı Tedavi Modelleri}

Türkiye'de şiddete/istismara doğrudan maruz kalan çocukların koruma ve tedavi yükümlülüğü yasalarla açık bir şekilde tanımlanmıştır (Çocuk Koruma Kanunu 5395, Sosyal Hizmetler ve Çocuk Esirgeme Kurumu Kanunu 2828, Ailenin Korunması ve Kadına Karşı Şiddetin Önlenmesine Dair Kanun 6284). Aile içi şiddet gibi içerisinde pek çok sorun alanını barındıran bir konuda tek hizmet sağlayıcılar sosyal çalışmacılar ya da sosyal hizmet uzmanları değildir. Sürece ruh sağliğı profesyonelleri de çoğu zaman girmektedir. Dolayısıyla güvenlik planı oluşturmanın yanı sıra söz konusu duruma maruz kalan çocukların ve gençlerin tedavi sürecinin de açıklanması önemli görülmektedir. Aile içi şiddete maruz kalan çocuklarla çalışırken kullanılan farklı modeller vardır. $\mathrm{Bu}$ modellerden etkililiği pek çok sayıda çalışma ile ortaya konulmuş çocuk ebeveyn psikoterapisi-aile içi şiddet (child parent psychotherapy-family violence), anababa çocuk etkileşim terapisi (parent child interaction therapy) ve travma odaklı bilişsel davranış̧̧ı terapi (trauma focused cognitive behavioral therapy) kısaca açıklanmıştır. Bu tedavi yöntemlerinden ilk ikisi daha küçük yaştaki çocuklara odaklanmakta ve özellikle anababa becerilerini geliştirmeyi amaçlamaktadır. Sonuncusu ise daha çok travma semptomlarının giderilmesine odaklanmaktadır.

\section{Çocuk Anababa Psikoterapisi}

Fraiberg'in (1980) yeni doğan-anababa psikoterapisi ve Bowlby'nin (1969) bağlanma teorisine dayanarak geliştirilmiştir. Beş yaşına kadar çocukların şiddete ya da travmaya maruz kalmalarından kaynaklanan anababa-çocuk ilişkisinin aksaması ya da olumsuz 
etkilenmesi durumlarında kullanılmaktadır (Ippen ve ark. 2010). Tipik olarak haftada bir uygulanan bu yöntem oturumlar sırasında çocuğun serbestçe oyun oynamasına, bu oyunlar sırasında çocuk ile anababası arasında kendiliğinden gelişen etkileşimlere odaklanmakta, terapist çocuğun tepkilerini aileye tercüme etmekte, çocuğun uyumsuz (maladaptive) davranışlarını ve anababanın uyumsuz davranışlarının üzerinde durmakta, anababalara gelişimsel konularda rehberlik etmekte, çocuk ve anababaları travmatik deneyimi konuşarak iletişim kurmaları konusunda teşvik etmekte ve bir travma öyküsü oluşturmaya çalışmaktadır. Bu şekilde terapide işlenmemiş korkutucu olaylar ele alınmaktadır (David ve Schiff 2015).

Çocuk anababa terapisi-aile içi şiddet programı ise birer saatlik 12 oturumda oluşur, bu oturumlarda terapistin yönlendirmesi ile anne çocuk ile etkili bir şekilde oyun oynar, ayrıca anne etkili koruyucu davranışları öğrenir. Bu yöntem annenin çocuğun duygusal durumlarını anlayıp, normalleştirmesine, duygusal destek verebilmesine, oyun yolu ile sağlıklı bir anne-çocuk ilişkisi gelişmesine odaklanır (Borrego ve ark. 2008).

\section{Anababa Çocuk Etkileşim Terapisi}

Sosyal öğrenme ve bağlanma teorisine dayanan, süresi 14-20 hafta arasında değişen 2-7 yaş arası gözlenen davranış problemleri sergileyen çocuklarla kullanılan bir modeldir (Timmer ve ark. 2010). Değişim için anababa eğitim programlarını ve olumlu anababalık stratejilerini kullanan bu yöntemde terapist çocuğun da yer aldığ1 oturumlarda, bireysel farklılıkları da gözeterek, çocuk ile anababa arasındaki işlevsiz ilişki biçiminin değiştirilmesi konusunda anababayı yönlendirir (Borrego ve ark. 2008). Tedavi modelinin ilk evresine çocuğun önderliğinde iletişim adı verilir. Buradaki amaç çocuk ile anababa arasındaki iletişimi geliştirmektir, ikinci evreye ise anababa önderliğinde iletişim $\operatorname{ad}_{1}$ verilir. Buradaki amaç ise çocuğun uyumunu geliştirmektir. Her bir evre bilgi verici bir saatlik bir oturumla başlar, uygulama sırasında ise çift taraflı aynanın olduğu bir odanın görünmez tarafında olan terapist kulaklıkla anababaya geri bildirim verir (Timmer ve ark. 2010).

\section{Travma Odakh Bilişsel Davranış̧̧ Terapi Modeli}

Temelde aşamalı maruz bırakma ilkelerine dayanmaktadır. Oturumlar terapist ve çocuk, anababa ve terapist ile anababa-çocuk-terapist oturumları şeklinde düzenlenmektedir (Cohen ve Mannario 2008). Tedavi travma ve istismara ilişkin genel bir psikoeğitim ile başlar, ardından stres kontrol teknikleri ve rahatlama eğitimi, duyguları ifade ve ayarlama, bilişsel başa çıkma, travma öyküsü oluşturma, bilişsel işlemleme, davranış düzenleme, anababa-çocuk oturumu ile sonlanır (TF-CBT Web 2005). Tedavinin her bir bileşeni çocuğun travmatik deneyimine maruz kalmayı gerektirir ve çocuk ile anababa tedavide üst basamaklara çıktıkça maruz bırakmanın yoğunluğu da artar (Cohen ve Mannario 2008).

Tedavinin temelinde travmatik olayı deneyimleyen kişinin travma sonrası stres bozukluğu semptomlarının travmaya verilen doğal bir tepki olduğunu bilmesi amaçlanır. Ancak yüksek düzeyde rahatsızlık yaratan travmanın hatırlatıcılarından kaçınmanın belirtileri arttırdığını anlaması, travmanın yarattığı yoğun duygular ile baş etme yöntemlerini öğrenmesinin önemli olduğu belirtilir. Bunların yanı sıra tedavide tetikleyiciler ve hatırlatıcılara aşamalı olarak maruz kalarak travma öyküsüne duyarsızlaşmasına odaklanılmaktadır (TF-CBT Web 2005). 


\section{Sonuç}

Birleşmiş Milletler Çocuk Hakları Sözleşmesinin 19 Maddesi çocukların her türlü kötü muamele, istismar ve ihmalden korunmasından önce ana babayı sonrasında da taraf devletleri sorumlu kılar. Unutulmamalıdır ki çocuklar aile içi şiddetin görünmeyen mağdurları olmaktadır ve şiddete tanıklık etmelerinin yanı sıra çoğu kez istismara da maruz kalmaktadırlar. Aile içi şiddete tanık olan ve şiddetin doğrudan mağduru olan çocuklarda akut ya da kronik çeşitli duygusal davranışsal problemler görülmektedir.

$\mathrm{Bu}$ durumda ilk yapılması gereken aile içi şiddetin önlenmesine yönelik çalışmalar yürütmektir. İstanbul Sözleşmesi (Kadınlara Yönelik Şiddet ve Aile İçi Şiddetin Önlenmesi ve Bunlarla Mücadeleye İlişkin Avrupa Konseyi Sözleşmesi) 34 ülke tarafindan 2011 yılında imzalanmıştır. Türkiye'nin bu sözleşmeyi ilk imzalayan ülke olması söz konusu soruna ilişkin hukuksal farkındalığın oluştuğunu gösterir niteliktedir. Bu sözleşme Türkiye'de 2014 y1lında yürürlüğe girmiştir. (Deutsche Welle 2015).

Türkiye'de aile içi şiddete yönelik programlar Aile ve Sosyal Politikalar Bakanl1ğı'nın tarafından yürütülmektedir. 2008-2010 yılları arasında yürütülen Avrupa Birliği destekli Sığınma Evleri Projesi ardından 2013 yılında Aile İçi Şiddetle Mücadele Projesi başlatılmıştır. 2013 yılından bu yana devam eden bu projenin hedefi 26 ilde şiddete/aile içi şiddete maruz kalan kadınlar için destek hizmetleri oluşturarak ve/veya mevcut hizmetleri geliştirerek kadınların şiddete karşı yeterli korunmaya sahip olmalarını sağlamaktır (Aile İçi Şiddetle Mücadele Projesi 2016). Şiddetin önlenmesine ilişkin bir diğer proje de Milli Eğitim Bakanlığ1 ve Avrupa Birliği iş birliği ile 2013 yılında yürütülmeye başlanan Çocuğa Yönelik Şiddetin Önlenmesi Projesi olup projenin hedeflerinden bir tanesi de "Çocuklara yönelik şiddetin önlenmesi ve müdahale edilmesi için okullardaki rehberlik ve psikolojik danışmanlık hizmetlerinin ve pilot illerdeki mevcut Psiko-sosyal Müdahale Ekiplerinin kapasitelerinin geliştirilmesi” olarak tanımlanmıştır. Proje kapsamında oluşturulan Şiddet Eylem Müdahale Planı ile konuya yönelik olarak bir farkındalık artışı ve konunun okullarda yürütülen rehberlik faaliyetlerine dahil edilmesi hedeflenmiştir (Çocuğa Yönelik Şiddetin Önlenmesi Projesi 2016).

Sözü edilen projelerin gerçekleştirmesi umut vericidir. Aile içi şiddete yönelik gelecekte yapılacak önleyici ve müdahale edici projeler kapsamında güvenlik planı hazırlama ve sözü edilen tedavi modellerinin Türk kültürüne uyarlaması yapılabilir. Ayrıca Türkiye'deki gereksinimlerin neler olduğuna ilişkin araştırmalar yapıldıktan sonra kültüre özgü yeni önleyici ve müdahale edici yaklaşımlar geliştirilebilir. Bu nokta da en önemli konu, yapılan çalışmaların etkililik araştırmalarıyla desteklenmesidir. Böylece etkisiz uygulamalar yerine işe yarayan ve bireylerin yüksek fayda sağladığı yaklaşımlar elde edilebilir. Ancak bu şekilde hem kaynakların ekonomik kullanımının hem de şiddetin önlenmesinin sağlanılabileceği düşünülmektedir.

Söz konusu projeler şiddetle mücadele açısından her ne kadar umut verici olsa da yapılan araştırmalar yeterli olmadığını göstermektedir. Nitekim aile içi şiddet ailenin kutsallığı, ailenin mahremiyeti, toplumsal cinsiyet rolleri, kadınların şiddetle baş etme biçimleri, toplumun ve kadınların şiddete ilişkin algıları gibi pek çok faktörün etken rol oynadığı bir sorundur (Kandemirci ve Kağnıcı 2014). Türkiye'de şiddetin bir terbiye biçimi olarak algılanması, bunun hem aile içinde hem de kamusal yaşamda meşru olarak görülmesi; şiddetin hem tekrarlamasına, hem de gizlenmesine yol açmaktadır (Ayan 2007). Aile içinde yaşanan şiddetin müdahale edilmeksizin sürmesi çocuklarda pek çok yakın dönemli ve uzun dönemli fiziksel ve ruhsal soruna yol açabildiği gibi, şiddetin 
çocuk tarafından model alınmasına ve sorunlar karşısında bir çözüm yolu olarak uygulanmasına ve ne yazık ki bu şekilde şiddetin nesil nesilden aktarımına yol açmaktadır. $\mathrm{Bu}$ kısır döngünün kırılması ancak aile içi şiddetin etkilerini eksiksiz biçimde kavranması ve buna ilişkin etkin müdahaleler ortaya konması ile mümkün olabilir.

Aile içi şiddet çocukların en temel ihtiyaçlarından biri olan güvenli bir ortam yerine güvensiz ve belirsiz bir ortamda yetişmelerine sebep olur. Bu ortamda büyüyen çocukların önceliği güvenlik olduğundan ilişkileri kontrol etme ve riski değerlendirmeyle meşguldürler, ebeveynlerinin duygusal ve psikolojik iyi oluşuna aşırı duyarlı olabilirler, ebeveynlerinin içinde bulunduğu anlaşmazlıkları kendi davranışları ile ilişkilendiriyor olabilirler (Johnston ve Straus 1999). Çocuğun kendini güvende hissetmesi tedavi sürecinin en önemli aşamalarından bir tanesidir. Bu nedenle bu çalışmada güvenlik planı hazırlama tekniğine detaylı bir şekilde değinilmiştir. Söz konusu teknik aile içi şiddete maruz kalan çocuklar ile çalışan psikoterapistler ve rehber öğretmenlerce kolaylıkla uygulanabilir.

Güvenlik planı hazırlamanın yanı sıra ruh sağlığı alanında önde gelen farklı üç tedavi modeli sunulmuştur. Bu yaklaşımlar, etkililiği araştırmalarla ortaya konulmuş tedavi yaklaşımları olup sözü edilen yaklaşımların sosyal hizmetler ve ruh sağllğı profesyonelleri tarafindan kullanılması, aile içi şiddet ya da istismar mağduru çocukların ruh sağlıklarının korunması açısından önemli görünmektedir. Ayrıca bu yaklaşımların uygulanabilirliğinin artırılması bakımından ilgili kurumların da uzman personelin çalışmalarını desteklemelerinin ve farklı uzmanlık alanları arasında işbirliğine gidilmesinin gerekli olduğu düşünülmektedir.

Aile içi şiddete maruz kalan çocuklarla çalışırken çocuğun yanı sıra anne ve babayı da tedavi sürecine dâhil etmek oldukça önemlidir. Şiddet gören kişilere yönelik destek programları, şiddet uygulayan kişilere yönelik öfke kontrol grupları, anababalara yönelik aile eğitimi programları gelişmiş ülkelerde sıklıkla başvurulan yöntemler arasındadır. Söz konusu bu yöntemlerin tedavi ile birlikte kullanılması ile her ne kadar aile içi şiddetin çocuk üzerindeki etkisi azaltılmaya çalış1lsa da kimi durumlarda çocuğun içinde bulunduğu riskli durum devam ediyor olabilir. Bu noktada yasal sistemin devreye girmesi, gerektiği takdirde çocuğun koruma altına alınması, şiddet uygulayan anne ya da baba ile uzman denetiminde görüşmesi ve hatta şiddet uygulayan anne ya da baba ile ilişkisinin tamamen kesilmesi başvurulmak zorunda kalınan kısıtlamalar arasındadır. Kısacası aile içi şiddetin çocuklar üzerindeki olumsuz etkileri ele alınırken çocuğun yanı sıra mağdur ve şiddeti uygulayan anababa da dâhil olmak üzere bütün aile sistemi üzerinde disiplinler arası bir yaklaşımla çalışılmasının büyük önem taşıdığı düşünülmektedir.

\section{Kaynaklar}

Aile İ̧i Şiddetle Mücadele Projesi (2013) Aile içi şiddetle mücadele projesi. http://www.siddetlemucadele.net/ (27.02.2016 tarihinde ulaşıldı).

Ayan S (2007) Aile içinde şiddete uğrayan çocukların saldırganlık eğilimleri. Anadolu Psikiyatri Dergisi, 8:206-214.

Barran D (2014) Effective help for children exposed to domestic abuse. J Fam Health Care, 24:10-12.

BorregoJr J, Gutow MR, Reicher S, Barker, CH (2008) Parent-child interaction therapy with domestic violence populations. J Fam Violence, 23:495-505.

Bowlby J (1969) Attachment and Loss. Vol. 1: Attachment. New York, NY, Basic Books.

CAADA (2014) In plain sight: effective help for children exposed to domestic abuse report. www.caada.org.uk (09.01.2015 tarihinde ulaşıldı). 
Campbell JC (2001) Safety planning based on lethality assessment for partners of batterers in intervention programs. J Aggress, Maltreat Trauma, 5:129-143.

Cohen JA, Mannario AP (2008) Trauma-focused cognitive behavioural therapy for children and parents. Child Adolesc Ment Health, 13:158-162.

Cohen JA, Mannario AP, Murray LK (2011) Trauma-focused CBT for youth who experience ongoing traumas. Child Abuse Neg, 35:637-646.

Çocuğa Yönelik Şiddetin Önlenmesi Projesi (2016) TC Milli Eğitim Bakanlığı Çocuğa Yönelik Şiddetin Önlenmesi Projesi. http://siddetinonlenmesi.meb.gov.tr/ (27.02.2016 tarihinde ulaşıldı).

David P, Schiff M (2015) Learning from bottom-up dissemination: Importing an evidence-based trauma intervention for infants and young children to Israel. Eval Program Plann, 53:18-24.

Davies J, Lyon E, Monti-Catania D (1998) Safety Planning with Battered Women: Complex Lives/Difficult Choices, 7th ed. California, Sage Publications.

Deutsche Welle (2015) Kadın hakları için referans 'İstanbul Sözleşmesi'. http://www.dw.com/tr/kad\%C4\%B1n-haklar\%C4\%B1i\%C3\%A7in-referans-istanbul-s\%C3\%B6zle\%C5\%9Fmesi/a-18264425 (27.02.2016 tarihinde ulaşıldı).

Dobson KS ed. (2009) Handbook of Cognitive-Behavioral Therapies. New York, Guilford Press.

Duyan GÇ (2011) Kadın Yoksulluğu. Ankara, Sosyal Hizmet Uzmanları Derneği Yayınları.

Enlow MB, Egeland B, Blood EA, Wright R0, Wright RJ (2012) Interpersonal trauma exposure and cognitive development in children to age 8 years: a longitudinal study. J Epidemiol Community Health, 66:1005-1010.

Espelage DL, Low S, Rao MA, Hong JS, Little TD (2013) Family violence, bullying, fighting, and substance use among adolescents: a longitudinal mediational model. J Res Adolesc, 24:337-349.

Evans SE, Davies C, DiLillo D (2008) Exposure to domestic violence: a meta-analysis of child and adolescent outcomes. Aggress Violent Behav, 13:31-140.

Fantuzzo JW, Fusco RA (2007) Children's direct exposure to types of domestic violence crime: a population-based investigation. J Fam Violence, 22:543-552.

Ferencik SD, Ramirez-Hammond R (2010) Trauma-Informed Care: Best Practices and Protocols for Ohio's Domestic Violence Programs. Ohio, Ohio Department of Mental Health.

Fraiberg S (1980) Clinical Studies in Infant Mental Health: The First Year of Life. US, Basic Books.

Ganley AL (1995) Improving the Health Care Response to Domestic Violence: A Resource Manual for Health Care Providers. San Francisco, Family Violence Prevention Fund.

Gezen M, Oral ET (2013) Attachment styles and degree of psychological symptoms in women staying in women staying in a shelter for battered women or in their home where they were exposed to violence. Düşünen Adam: The Journal of Psychiatry and Neurogical Sciences, 26:65-71.

Gibson M (2014) Narrative practice and the signs of safety approach: engaging adolescents in building rigorous safety plans. Child Care in Practice, 20:64-80.

Herman JL (2015) Trauma and Recovery. US, Basic Books.

Herman-Smith R (2013) Intimate partner violence exposure in early childhood: an ecobiodevelopmental perspective. Health Soc Work, 38:231-239.

Holden GW (2003) Children exposed to domestic violence and child abuse: terminology and taxonomy. Clin Child Fam Psychol Rev, 6:151-160.

Holt S, Buckley H, Whelan S (2008) The impact of exposure to domestic violence on children and young people: a review of the literature. Child Abuse Negl, 32:797-810.

Horton E, Murray CE, Garr B, Notestine L, Flasch P, Higgins-Johnson C (2014) Provider perceptions of safety planning with children impacted by intimate partner violence. Child Youth Serv Rev, 42:67-73.

Ippen CG, Harris WW, Van Horn P, Lieberman AF (2011) Traumatic and stressful events in early childhood: can treatment help those at highest risk? Child Abuse Negl, 35:504-513.

Johnston JR, Straus RB (1999) Traumatized children in supervised visitation: what do they need? Fam Concil Courts Rev, 37:135158.

Başbakanlık Kadının Statüsü Genel Müdürlüğü (2009) Türkiye'de Kadına Yönelik Aile l̇çi Şiddet. Ankara, T.C. Başbakanlık Kadının Statüsü Genel Müdürlüğü.

Kandemirci D, Kağnıcı DY (2014) Kadına yönelik aile içi şiddetle baş etme: çok boyutlu bir inceleme. Türk Psikoloji Yazıları, 17(33):1-12.

Kıvrak Y, Gey N, Kıvrak HA, Kokaçya MH, Çöpoğlu ÜS, Arı M (2015) Kadına yönelik eş şiddeti, çocukluk travmaları, depresyon ve yaşam kalitesi: Toplum temelli çalışma. Anadolu Psikiyatri Dergisi, 16:314-322. 
Lewis AJ, Austin E, Knapp R, Vaiano T, Galbally M (2015) Perinatal maternal mental health, fetal programming and child development. Healthcare (Basel), 3:1212-1227.

Lindhorst T, Nurius P, Macy RJ (2005) Contextualized assessment with battered women: Strategic safety planning to cope with multiple harms. J Soc Work Educ, 41:331-352.

Lourenço de Silva AMV, Taquette SR, Hasselmann MH (2014) Family violence and body mass index among adolescents enrolled in the Bolsa Familia Program and treated at a primary care clinic. Cad Saude Publica, 30:645-655.

MacMillan HL,Wathen CN, Varcoe CM (2013) Intimate partner violence in the family: considerations for children's safety. Child Abuse Negl, 37:1186-1191.

Margolin G, Vickerman KA (2011) Posttraumatic stress in children and adolescents exposed to family violence: I. overview and Issues. Prof Psychol Res Pr, 38:613-619.

Miller LE, Howell KH, Hunter EC, Graham-Bermann SA (2012) Enhancing safety-planning through evidence-based interventions with preschoolers exposed to intimate partner violence. Child Care in Practice, 18:67-82.

Mor Çatı Kadın Sığınağı Vakfı (2016) Şiddete uğradığııızda. https://www.morcati.org.tr/tr/8-mor-cati-kadin-siginagi-vakfi/3siddete-ugradiginizda (2.01.2016 tarihinde ulaşıldı)).

Osofsky JD (1995) Children who witness domestic violence: the invisible victims. Soc Policy Rep, 9(3):1-16.

Osofsky JD (1999) The impact of violence on children. Future Child, 9(3):33-49.

Osofsky JD (2005) The role of non-mental-health professionals-the professional view point: the effects of exposureto violence on children of different ages: prevention and intervention-effective collaboration with police and court. In Developing Strategies to Deal with Trauma in Children (Eds. J Donnelly, A Kovacova, H Osofsky, J Ososfsky, C Paskell, J Salem-Pickartz):77-88. Amsterdam, I0S Press.

Peled E (2011) Abused women who abuse their children: a critical review of the literature. Aggress Violent Behav, 16:325-330.

Pelendecioğlu B, Bulut S (2009) Çocuğa yönelik aile içi fiziksel istismar. Abant İzzet Baysal Üniversitesi Eğitim Fakültesi Dergisi, 9:49-62.

Polat 0 (2007) Tüm Boyutlarıyla Çocuk İstismarı 1. Tanımlar. Ankara, Seçkin Yayıncılık.

Roediger C (2009) Şema Terapi Nedir? Şema Terapinin Temellerine, Modellerine ve Uygulamasına Giriş (Çeviri Ed. S Ataman). Ankara, Nobel Yayıncılık.

Şenol D, Yıldız S (2013) Kadına Yönelik Şiddet Algısı-Kadın ve Erkek Bakış Açılarılla. Ankara, Mutlu Çocuklar Derneği Yayınları.

Temiz M, Beştepe E, Yıldız 0̈, Küçükgöncü S, Yazıcı A, Çalıkuşu C, Erkoç §̧ (2014) Yataklı psikiyatri servisinde tedavisi süren kadın hastalarda aile içi şiddetin hastalık tanıları ve hastalık süreciyle ilişkisi, Nöropsikiyatri Arşivi, 51:1-10.

TF-CBT Web (2005). A web based learning course for trauma focused cognitive behavioral therapy. https://tfcbt.musc.edu/ (12.01.2015 tarihinde ulaşıldı).

The National Domestic Violence Hotline (2015) Path to safety. http://www.thehotline.org/help/path-to-safety/ (12.01.2015 tarihinde ulaşıldı).

Tıraş̧̧ Y, Gören S (2007) Çocuk istismarı ve inmali. Dicle Tıp Dergisi, 34:70-74.

Timmer S G, Ware LM, Urquiza AJ, Zebell NM (2010) The effectiveness of parent-child interaction therapy for victims of interparentalviolence. Violence Vict, 25:486-503

Turnell A (2012) The Signs of Safety Comprehensive Briefing Paper. Perth, Western Australia, The Resolutions Consultancy.

Turnell A, Edwards S (1999) Signs of safety: a solution and safety oriented approach to child protection casework. New York, NY, Norton.

TÜiK (2014) Kadına yönelik aile içi şiddet istatistikleri. http://www.tuik.gov.tr/VeriTabanlari.do?ust_id=109\&vt_id=31 (21.12.2015 tarihinde ulaşıldı).

UNICEF (2006) Behind The Closed Doors: The Impact of Domestic Violenece on Children. New York, UNICEF.

Ünal F (2008) Ailede çocuk istismarı ve ihmali. Türkiye Sosyal Araştırmalar Dergisi, 12:9-18.

Waugh F, Bonner M (2002) Domestic violence and child protection: Issues in safety planning. Child Abuse Rev, 11:282-295.

WHO (2013) Global and Regional Estimates of Violence against Women: Prevalence and Health Effects of Intimate Partner Violence and Non-Partner Sexual Violence. Geneva, WHO.

WH0 (2104). Child maltreatment. http://www.who.int/mediacentre/factsheets/fs150/en/ (09.01.2016 tarihinde ulaşıldı).

Wolfe DA, Crooks CV, Lee V, McIntyre-Smith A, Jaffe PG (2003) The effects of children's exposure to domestic violence: a metaanalysis and critique. Clin Child Fam Psychol Rev, 6:171-187.

Young JE, Klosko JS, Weishaar ME (2003) Schema Therapy: A Practitioner's Guide. New York, Guilford Press. 
Melis Sedef Kahraman, Adalet Bakanlı̆ı 6. Aile Mahkemesi, Ankara; Gökçe Çokamay, Ankara Üniversitesi, Ankara.

Yazışma Adresi/Correspondence: Melis Sedef Kahraman, Adalet Bakanlı̆ı̆ 6 Aile Mahkemesi, Ankara, Turkey.

E-mail: sedefy82@gmail.com

Bu makale ile ilgili herhangi bir çıkar çatışması bildirilmemiş̧tir · No conflict of interest is declared related to this article

Çevrimiçi adresi / Available online: www.cappsy.org/archives/vol8/n04/

Geliş tarihi/Submission date: 28 Şubat/February 28, 2016 · Kabul Tarihi/Accepted 9 Mayıs/May 9, 2016

Psikiyatride Güncel Yaklaşımlar - Current Approaches in Psychiatry 